\title{
Bovine papillomavirus productive infection in cell cultures: First evidences
}

\author{
Rodrigo Pinheiro Araldi ${ }^{1,2}$, Thatiana Correa de Melo ${ }^{1}$, Silvio Roberto Consonni ${ }^{3}$, Jacqueline Mazzuchelli de Souza ${ }^{1,2}$, Diego Grando \\ Módolo $^{1}$, Suelly Muro Reis Assaf ${ }^{1}$, Thaylene Alexandra Nascimento de Lima ${ }^{1}$, Roberta Fiusa Magnelli ${ }^{1,2}$, Diva Denelle Spadacci Morena ${ }^{4}$, \\ Rodrigo Franco de Carvalho ${ }^{1}$, Willy Beçak ${ }^{1}$ and Rita de Cassia Stocco ${ }^{1 *}$ \\ ${ }^{1}$ Genetics Laboratory, Butantan Institute, São Paulo, São Paulo, 05503-900, Brazil \\ ${ }^{2}$ Biotechnology Interunits Post-graduation Program, Biomedical Science Institute, University of São Paulo (USP), São Paulo, São Paulo, 03178-200, Brazil \\ ${ }^{3}$ Department of Tissue Biology and Biochemistry, Biology Institute, State University of Campinas (UNICAMP), Campinas, São Paulo, 13083-862, Brazil \\ ${ }^{4}$ Fisiopathology Laboratory, Butantan Institute, São Paulo, São Paulo, 05503-900, Brazil
}

\begin{abstract}
Bovine papillomavirus (BPV) is the etiological agent of bovine papillomatosis (BP), infectious disease, characterized by the presence of multiples papillomas that can regress spontaneously or progress to malignances. Although recognized as mutagen, BPV action following cancer initiation remains few explored, since studies about cancer progression and metastasis are based on cell cultures. The lack of attention to in vitro models is a reflection of the papillomavirus replication paradigm, which is dependent of epithelium cell differentiation. Since 2008, we have explored the potential of cell lines derived from BPV-infected neoplasms as model to study the oncogenic process. In this study, we described BPV productive infection in cell lines derived from cutaneous papilloma, fibropapilloma and esophageal carcinoma (EC) in which BPV DNA sequences were previously detected by PCR. Considering that the immunodetection of L1 capsid protein is the main evidence of productive infection, we analyzed the expression of this protein by immunofluorescence and flow cytometry. Results showed the immunodetection of L1 protein in cell lines derived from cutaneous papilloma, fibropapilloma and EC, but not in cells derived from BPV-free normal skin. We also observed the presence of spherical and electron-dense particles, with 41.02-61.94 nm diameter in cytoplasmic vesicles of cells in the sixth passage of cutaneous papilloma, fibropapilloma and EC, being compatible with the expected BPV morphology. Cells derived from BPV-free normal skin, in turn, showed membranous particles up to 75.00 nm not compatible with BPV morphology. These results suggest the BPV productive infection in cells lines derived from BPV-infected neoplasm, reinforcing that these cells are useful models to study the viral biology and pathogenesis.
\end{abstract}

\section{Highlights}

- Bovine papillomavirus (BPV) cause multiples papillomas that can regress or progress to malignances;

- BPV action following cancer initiation remains few explored;

- Identification of BPV L1 capsid protein and virion-like particles in cytoplasmic vesicles of cell lines derived from BPVinfected cutaneous papilloma, fibropapilloma and esophageal carcinoma;

- Cell lines derived from BPV-infected neoplasm can be considered useful model to study the viral biology and pathology.

\section{Introduction}

Bovine papillomavirus (BPV) is the etiological agent of bovine papillomatosis (BP), infectious and neoplastic disease characterized by the presence of multiples papillomas that can regress spontaneously or progress to malignance in the presence of co-factors [1-8]. BPV is a cosmopolitan virus, being present in all continents [1,9], leading to important economic loses worldwide [10]. About $60 \%$ of Brazilian cattle herd are infected by BPV [2]. However, this percentage can be greater, since the virus can lead to asymptomatic infections $[11,12]$.

Currently there are $15 \mathrm{BPV}$ types described, which are classified in four genres: Deltapapillomavirus (BPV-1, 2, 13 and 14),
Epsilonpapillomavirus (BPV-5 and 8), Xipapillomavirus (BPV-3, 4, 6, 9, 10, 11, 12 and 15) and Dyoxipapillomavirus (BPV-7) [13-15].The Xipapillomavirus infects epidermis, causing true papillomas, while Delta and Epsilonpapillomavirus (BPV-5) can infect both epidermis and dermis, resulting in fibropapillomas [16-18]. Although the papillomaviruses (PVs) are recognized as specie-specific, $\mathrm{BPV}$ is able to infect felines [19], buffaloes [20-22], giraffe [23,24], tapirs [25], zebra [26], yaks [27,28] and horses [29-31]. In equines, BPV is the causative agent of sarcoid, invasiveness but non-metastatic fibroblastic benign neoplasm [32] that affects $11.5 \%$ of horses worldwide [33]. Due to the ability to infect different species and in function of morphological and pathogenic similarities with human papillomavirus (HPV), BPV is considered a useful model to study the HPV-associated oncogenic process [8,34-36].

Although recognized as oncogenic viruses by induce mutation [2,11,37-40] and transformation [41-43], the action of BPV following cancer initiation remains unclear [36]. The reason for this is the absence of in vitro virus replication and, therefore, the lack of models

Correspondence to: Rita de Cassia Stocco, Genetics Laboratory, Butantan Institute, São Paulo, 05503-900, Brazil, Tel: +55 11 2627-9701; e-mail: rita. stocco@butantan.gov.br

Key words: papillomaviruses, primary cell culture, productive infection

Received: April 07, 2017; Accepted: April 24, 2017; Published: April 26, 2017 
based on cell culture systems [44], which are mandatory to study the BPV action in cancer progression and metastasis [36]. This occur because, according to the BPV natural history, the viral replication is dependent of cell differentiation [45-47]. Considering the paradigm of PVs replication cycle, the expression of capsid proteins (L1 and L2) and viral assembly are only verified in most differentiated epithelium layers (hypergranulous) [48-50]. Due to this paradigm, little attention has been given to the primary cultures derived from BPV-infected tissues as model to study the pathogenic mechanism of PVs. However, in last decades, studies have described the presence of BPV DNA sequences, transcripts, proteins and virus-like particles in sites before not recognized as permissive to productive infection due to the absence of cell differentiation, including peripheral blood [51,52] and placenta [53]. Similar results have been also described in humans, in which sequences of HPV were verified in blood and semen [54,55]. In addition, Cerqueira et al. [47] currently demonstrated the cell-free assembly HPV-16 capsid. These results indicate the need to review the PVs natural history, as proposed by Munday [34].

The in vitro models, based on cell culture systems, have been extensively employed to study the oncogenic potential of PVs oncoproteins (E5, E6 and E7) or evaluate the interaction of virus with host cell, as showed in table 1. Results of these studies demonstrate that these systems mimetic several phenotypes observed in vivo (table 2), reinforcing the potential of these cell cultures as useful models to study the pathogenic mechanism of PVs. In this sense, since 2008, our group has demonstrated the potential of cell lines derived from BPV-infected neoplasm as model to study the cytogenetic $[40,56]$ and biochemical alterations induced by BPV [36,57]. Currently, we reported the maintenance of BPV DNA sequences during six passages of cell lines derived from cutaneous papilloma, fibropapilloma and esophageal carcinoma, suggesting an in vitro productive infection [57]. We also verified that these cells lines present a stem-cell and migratory biomarker phenotype acquisition, suggesting that in vitro systems are useful models to study the metastasis [58]. Despite these data, cell lines derived from BPV-infected cutaneous papilloma, fibropapilloma and esophageal carcinoma remains considered as non-permissive to productive infection. Based on this, we investigated the expression of BPV L1 capsid protein and the presence of virus particle by electron transmission microscopy in order to evaluate a possible productive infection in in vitro systems.

\section{Material and methods}

\section{Ethics statement}

This study was approved by the Ethic Committee on Animal Use of São Paulo Federal University (UNIFESP, process 1829/09).

\section{Primary cell culture establishment}

Three samples of skin papilloma were collected from three adult bovines showing bovine papillomatosis (Bos taurus, Simmental breed). One fragment of normal skin, without morphological alteration, was collected from 8 mouths aged. Samples of cutaneous papilloma, fibropapilloma and esophageal carcinoma were collected from adults presenting clinical symptoms of esophageal carcinoma. Tissue samples were collected by a veterinarian. Samples were washed in PBS with $2 \%$ amphotericin B and 3\% penicillin/streptomycin (Cultilab, Brazil) and transported to Genetics Laboratory of Butantan Institute in Dulbecco medium (DMEM), supplemented with $2 \%$ amphotericin B and $3 \%$ penicillin/streptomycin (Cultilab, Brazil).
Table 1. Summary of studies involving cell lines and papillomavirus. Studies based on $\mathrm{BPV} / \mathrm{HPV}$ gene transfection.

\begin{tabular}{|l|l|l|}
\hline \multicolumn{1}{|c|}{ Cell type } & \multicolumn{1}{|c|}{ Results } & Reference \\
\hline Pancreatic keratinocyte & HPV-16 E6/E7 promotes cell immortalization & {$[70]$} \\
\hline Ectocervix keratinocyte & HPV-16 E6/E7 promote cell immortalization & {$[71]$} \\
\hline $\begin{array}{l}\text { Normal foreskin } \\
\text { keratinocyte }\end{array}$ & E6 increases telomerase activity & {$[72,73]$} \\
\hline COS7 cells & $\begin{array}{l}\text { HPV-1 and 8 E6 interacts with E6AP (ubiquitin) } \\
\text { and p53 }\end{array}$ & {$[74]$} \\
\hline $\begin{array}{l}\text { Normal foreskin } \\
\text { keratinocyte }\end{array}$ & $\begin{array}{l}\text { HPV-16 E6 promotes epithelium stratification } \\
\text { reduction }\end{array}$ & {$[75]$} \\
\hline $\begin{array}{l}\text { Immortalized } \\
\text { keratinocyte }\end{array}$ & Evidences of HPV-16 productive infection & {$[76]$} \\
\hline Murine C127 cells & $\begin{array}{l}\text { HPV-16 and BPV-1 E6 promotes focal adhesion } \\
\text { decrease }\end{array}$ & {$[77-79]$} \\
\hline $\begin{array}{l}\text { Wart and squamous } \\
\text { carcinoma }\end{array}$ & $\begin{array}{l}\text { HPV E6 inhibits apoptosis in response to UV } \\
\text { damage }\end{array}$ & {$[80]$} \\
\hline $\begin{array}{l}\text { Normal foreskin } \\
\text { keratinocyte }\end{array}$ & HPV-16 E6/E7 induce cytogenetic aberration & {$[81,82]$} \\
\hline Chondrocyte & $\begin{array}{l}\text { HPV-16 E6/E7 promotes immortalization and } \\
\text { collagen type II expression }\end{array}$ & {$[83]$} \\
\hline $\begin{array}{l}\text { Normal foreskin } \\
\text { keratinocyte }\end{array}$ & $\begin{array}{l}\text { HPV-16 E6 induces p53 degradation and p53 and } \\
\text { hTERT expression, increasing telomerase activity }\end{array}$ & {$[84]$} \\
\hline $\begin{array}{l}\text { Normal foreskin } \\
\text { keratinocyte }\end{array}$ & $\begin{array}{l}\text { HPV-16 E6/E7 induce irreversible epitelial- } \\
\text { mesenchymal transition }\end{array}$ & {$[85]$} \\
\hline Cervical keratinocyte & $\begin{array}{l}\text { HPV-16 E5 interacts with endoplasmic reticulum } \\
\text { membrane }\end{array}$ & {$[86]$} \\
\hline $\begin{array}{l}\text { Normal foreskin } \\
\text { keratinocyte }\end{array}$ & $\begin{array}{l}\text { HPV-16 E6/E7 promote epigenetic alterations in } \\
\text { host cell }\end{array}$ & {$[87]$} \\
\hline $\begin{array}{l}\text { Normal foreskin } \\
\text { keratinocyte }\end{array}$ & HPV-16 E1^E4 induce keratin reorganization \\
\hline $\begin{array}{l}\text { Normal foreskin } \\
\text { keratinocyte }\end{array}$ & BPV-1 E2 stimulates cell migration & {$[88]$} \\
\hline Keratinocyte (PM1) & $\begin{array}{l}\text { HPV-8 E2, E6 e E7 promote the stem-cell } \\
\text { phenotype acquisition }\end{array}$ & {$[89]$} \\
\hline HEK293 cells & {$[90]$} \\
\hline
\end{tabular}

Table 2. Summary of studies involving cell lines and papillomavirus. Studies based on BPV-infected cell lines.

\begin{tabular}{|l|l|l|}
\hline Cell type & Results & References \\
\hline Keratinocyte & $\begin{array}{l}\text { Viral suspension addition in bovine } \\
\text { epithelium cells promotes cell } \\
\text { transformation and acidification }\end{array}$ & {$[93]$} \\
\hline Papilloma and fibropapilloma & $\begin{array}{l}\text { Verified cytogenetic aberration in } \\
\text { chromosomes 8 and 14 of BPV1.69 } \\
\text { transgenic mouse-derived papilloma }\end{array}$ & {$[94]$} \\
\hline $\begin{array}{l}\text { Papilloma, fibropapilloma, } \\
\text { urinary bladder and esophageal } \\
\text { carcinoma }\end{array}$ & $\begin{array}{l}\text { Establishment of cell lines and } \\
\text { identification of BPV }\end{array}$ & {$[56]$} \\
\hline Papilloma & Cytogenetic aberration & {$[40]$} \\
\hline & Primary culture establishment & {$[95]$} \\
\hline
\end{tabular}

Each sample was divided in three fragments, which were destined to: (1) primary cell culture establishment, (2) BPV molecular identification and (3) histopathological analysis. For primary cell culture establishment, the tissue was fragmented mechanically, using a sterile scalpel, which were washed three times PBS with $2 \%$ amphotericin B and 3\% penicillin/streptomycin. Tissue fragments were treated with $0.01 \%$ collagenase (Sigma, Germany) at $37^{\circ} \mathrm{C}$ for 15 minutes. The enzymatic product digestion was transferred to three culture flasks of $25 \mathrm{~cm}^{2}$, containing $5 \mathrm{~mL}$ of DMEM medium supplemented with $10 \%$ of fetal bovine serum (FBS) and $1 \%$ of penicillin/streptomycin (complete medium) at $37^{\circ} \mathrm{C}$. Culture flasks were incubated at $37^{\circ} \mathrm{C}$, with $5 \% \mathrm{CO}_{2}$ atmosphere until a confluence of $80 \%$. From this step, cells were treated with trypsin solution and expanded in culture flasks. One culture flask of each cell lineage obtained was cryopreserved in 
freezing medium (70\% DMEM, 10\% dymethylsulphoxyde and $20 \%$ FBS) and stocked at $-196^{\circ} \mathrm{C}$. These cell lines are part of biological collection of Genetics Laboratory. Cell employed in this study were cultivated until sixth passage (P1-P6) and subjected to morphological analysis by phase contrast using the Nikon Eclipse Ti (Nikon, Japan) inverted microscopy. Images were acquired using the NIS-Elements $\mathrm{Br}$ version 3.0 (Nikon, Japan) in total magnification of 100 and 200X. The molecular identification of BPV DNA sequences were performed by PCR using specific primers for BPV-1, 2 and 4, the most frequent virus types verified globally. PCR results are available in Araldi, et al. [57].

\section{Analysis of viral proteins}

\section{Immunofluorescence}

A total of $1 \times 10^{5}$ cells were seeded per well, employing a six-well plate, containing $2 \mathrm{~mL}$ of complete DMEM medium and using a $24 \times$ $24 \mathrm{~mm}$ sterile cover slip. Cells were incubated at $37^{\circ} \mathrm{C}$, with $5 \% \mathrm{CO}_{2}$ atmosphere, until a confluency of $80 \%$ (about 24 hours). The medium was removed and cells were washed three times with sterile PBS for 5 minutes. Cells were fixated with $4.0 \%$ formalin, diluted in PBS, at $4^{\circ} \mathrm{C}$ for 30 minutes and then washed three times with PBS for 5 minutes. Cells were permeabilized with $0.01 \%$ Triton X-100 (Sigma, Germany), diluted in PBS, at $4^{\circ} \mathrm{C}$ for 10 minutes. Cells were washed once with PBS and incubated overnight at $4^{\circ} \mathrm{C}$ with anti-L1 [BPV-1/1H8 + CAMVIR] (Abcam, Cambridge, UK) at a 1:100 dilution in 1\% of BSA. Cells were washed three times with PBS under described conditions and then incubated at $4^{\circ} \mathrm{C}$ for 3 hours with anti-mouse IgG-FITC (Sigma, Germany), at dilution of 1:100 in $1.0 \%$ of BSA. A cutaneous papilloma 01 cell line, incubated only with secondary antibody, was used as negative control. Cells were washed three times with PBS and cover slips were mounted on slides, using $20 \mu \mathrm{L}$ of ProLong Gold (Invitrogen, Carlsbad, USA) with DAPI. Slides were analyzed in Axio Scope A1 fluorescent microscope (Carls Zeiss, Germany) under total magnification of 400X. This analysis was performed in third passage (P3).

\section{Flow cytometry}

Cell lines were seeded in culture flasks of $25 \mathrm{~cm}^{2}$ with $5.0 \mathrm{~mL}$ of complete DMEM medium. Cells were subjected to monolayer disaggregation with $2 \mathrm{~mL}$ of Trypsin solution, centrifuged at $400 \mathrm{x} \mathrm{g}$ for 5 minutes. Cells were transferred to $1.5 \mathrm{~mL}$ polypropylene tubes and fixed in $1.0 \mathrm{~mL}$ of $1.0 \%$ formalin solution at $4^{\circ} \mathrm{C}$ for 2 hours. The material was centrifuged under described conditions, and washed twice with $1.0 \mathrm{~mL}$ of PBS at $4^{\circ} \mathrm{C}$ to remove the formalin residues. Cell were incubated with $1.0 \% \mathrm{BSA}$ at $4^{\circ} \mathrm{C}$ for 20 minutes, washed once with PBS, and incubated overnight at $4^{\circ} \mathrm{C}$ with primary antibodies showed in table 3. Cells were centrifuged under described conditions and washed twice with PBS at $4^{\circ} \mathrm{C}$. The material was incubated at $4^{\circ} \mathrm{C}$ for 2 hours with anti-mouse IgG1 conjugated with Alexa Fluor 488 secondary antibody (Invitrogen, Carlsbad, USA) at 1:200 dilution. Next, cells were washed with PBS, centrifuged under described conditions, and resuspended in $100 \mu \mathrm{L}$ of PBS. The material was analyzed in FACSCalibur (BD Bioscience, USA), employing the CellQuest software (BD Bioscience, USA). A total of 10,000 events were analyzed using the FlowJo software (TreeStar, Oregon, USA). Analysis were based on the percentage of immunostained cells. Cutaneous papilloma 01 cell line incubated with only secondary antibody was used as control. Analysis were performed in third passage (P3).

\section{Electron microscopy (EM)}

Cell lines were seeded in a six-well plate, containing a sterile cover slip/well, with $2 \mathrm{~mL}$ of complete medium until forming a confluence
Table 3. Summary of studies involving cell lines and papillomavirus. Studies based on HPV-infected cell lines.

\begin{tabular}{|l|l|l|}
\hline \multicolumn{1}{|c|}{ Cell type } & \multicolumn{1}{c|}{ Results } & References \\
\hline Laryngeal keratinocyte & HPV promotes tight junction reduction & {$[96]$} \\
\hline Cervical carcinoma & $\begin{array}{l}\text { Identification of HPV-16 and 18 by } \text { in situ } \\
\text { hybridization }\end{array}$ & {$[97]$} \\
\hline $\begin{array}{l}\text { Skin squamous } \\
\text { carcinoma }\end{array}$ & HPV-16 promotes in vitrodifferentiation & {$[98]$} \\
\hline Laryngeal carcinoma & $\begin{array}{l}\text { Addition of retinoic acid reduces the viral } \\
\text { DNA content and modulates the epithelium } \\
\text { differentiation }\end{array}$ & {$[99]$} \\
\hline Cervical carcinoma & $\begin{array}{l}\text { HPV promotes ATP-dependent Cl- channel } \\
\text { activation, increasing the cellular volume }\end{array}$ & {$[100]$} \\
\hline $\begin{array}{l}\text { HeLa, CaSki and } \\
\text { cervical carcinoma }\end{array}$ & HPV-16 E6 promotes VEGF upregulation & {$[101]$} \\
\hline $\begin{array}{l}\text { HeLa and SiHa } \\
\text { Oropharyngeal } \\
\text { squamous carcinoma }\end{array}$ & $\begin{array}{l}\text { Viral replication induces genomic instability } \\
\text { translocation }\end{array}$ & {$[102,103]$} \\
\hline
\end{tabular}

of $80-90 \%$. Medium was removed by aspiration and cells were fixated with $2.5 \%$ glutaraldehyde buffer for one hour at $4^{\circ} \mathrm{C}$. The material was washed five times with cacodylate buffer for two minutes/wash. Cells were incubated with $1 \%$ osmium tetroxide $\left(\mathrm{OsO}_{4}\right)$, diluted in $0.1 \mathrm{M}$ cacodylate buffer, containing $3 \mathrm{mM} \mathrm{CaCl}_{2}$ and $0.8 \%$ potassium ferrocyanide, for 30 minutes at $4^{\circ} \mathrm{C}$. The material was washed five times with ultrapure water and, later, contrasted with $2 \%$ uranyl acetate for 1 hour at room temperature. Cells were washed with ultrapure water and dehydrated with increasing concentrations of alcohol $(20 \%, 50 \%$, $70 \%, 80 \%, 90 \%$, and $100 \%$ ) at $4^{\circ} \mathrm{C}$ for three minutes. The material was subjected to additional dehydration with absolute ethanol at room temperature for three minutes. Cells were embedded in 1:1 solution of Epon-ethanol, under agitation, for 30 minutes at room temperature. We performed four complete exchanges of Epon resin with intervals of one hour except for an overnight interval, which was the last one. The material was transferred to $60^{\circ} \mathrm{C}$ for 72 hours, to polymerize the resin. Blocks were subjected to ultrafine cuts, which were analyzed in JEM-2100 transmission electron microscopy (JEOL Solution, USA). Morphometric analysis was performed using the AxioVision 4.9.1 software (Carl Zeiss, Germany). This analysis was performed in sixth passage (P6) to confirm the presence of virus particles. Morphometric analysis was performed using the AxioVision version 4.1.9.0 software (Carl Zeiss, Germany). Statistical analysis was performed based on medium diameter of electron-dense spherical particles detected by EM.

\section{Results}

\section{Histopathological analysis of tissue fragments}

Histopathological analysis of BPV-free normal skin, used as control, showed the absence of morphological alterations, presenting both epidermis and dermis preserved (Figure 1). Cutaneous papilloma and fibropapilloma samples showed morphological alterations in epidermis compatible to those verified in BPV infection: hyperkeratosis, koilocytosis, acanthosis and hypergranulosis (Figure 1). Fibropapillomas showed a fibroelastic dermis, with extensive fibroblastic proliferation (Figure 1), which was not verified in cutaneous papilloma (Figure 1). Esophageal carcinoma sample showed a tissue disorganization, with the presence of mitotic and pleomorphic cells, presenting hydropic degereration in spinous layer (Figure 1). It was also observed the presence of transformed cell islands into dermis (Figure 1), characterizing an esophageal epidermoid carcinoma.

\section{Morphological analysis of primary cell cultures}

Results showed the presence of both epithelioid and fibroblastoid cells in primary cultures of BPV-free normal skin, skin papilloma, 


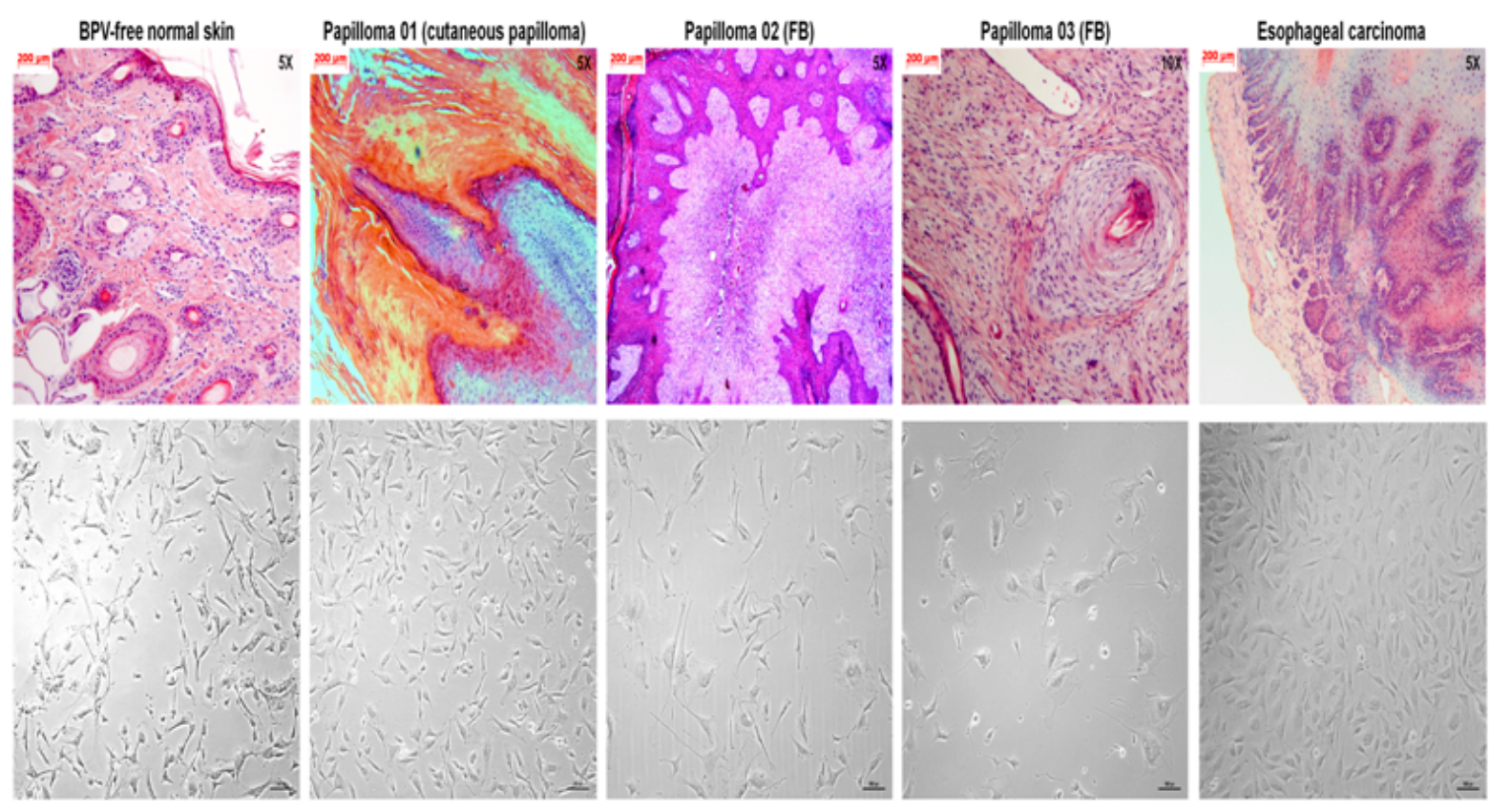

Figure 1. Photomicrographs of histological cuts and phase contrast $\mathrm{f}$ cell lines derived from different tissue fragments: A) BPV-free normal skin, B) cutaneous papilloma (papilloma 01), C) fibropapilloma (papilloma 02), D) fibropapilloma (papilloma 03) and E) esophageal carcinoma. Histopathology analysis shows tissue preservation of BPV-free normal skin. Tissue fragments of both cutaneous papilloma and fibropapilloma showed acanthosis, parakeratotic and orthokeratotic hyperkeratosis and hyperkeratosis. Fibropapillomas show a fibroelastic stroma, with high fibroblastic proliferation. Analysis shows tissue disorganization in esophageal carcinoma tissue. Morphological analysis shows the preservation of apical-basal polarity of BPV-free normal skin cells. By the opposite, cells derived from cutaneous papilloma, fibropapilloma and esophageal carcinoma show the loss of polarity and the acquisition of fibroblastoid phenotype. Images obtained with total magnification of $50 \mathrm{X}$

fibropapillomas and esophageal carcinoma (Figure 1). However, we verified the prevalence of fibroblstoid cells in primary culture of BPVinfected tissues, but not in normal skin (Figure 1).

\section{Analysis of BPV L1 protein expression}

We verified the expression of L1 proteins in primary cell cultures of cutaneous papilloma (papilloma 01), fibropapilloma (papilloma 02 and 03) and esophageal carcinoma, but not in BPV-free normal skin cells (Figure 2). Results of immunofluorescence showed the nuclear and cytoplasmic labelling of BPV L1 capsid protein (Figure 2). These results were confirmed by flow cytometry, which showed high levels of L1 expression specially in cell lines derived from cutaneous papilloma (papilloma 01), fibropapilloma (papilloma 02 and 03) and esophageal carcinoma (Figure 2). Negative controls of both immunofluorescence and flow cytometry showed the absence of labelling (Figure 2).

\section{Identification of BPV-like particles in primary cell cultures}

Results of electron microscopy showed the presence of electrondense spherical structures with 41.02-61.94 nm and icosahedral morphology, present in cytoplasmic vesicles of cutaneous papilloma, fibropapillomas and esophageal carcinoma cells (Figures 3), but not in BPV-free normal skin cells (Figures 4 and 5). These structures are compatible with the expected morphology of BPV particles [51,59].

\section{Discussion}

Since 2008, our group have explored the potential of both primary cell cultures and cell lines derived from primary cell cultures of BPVinfected benign and malignant neoplasms as model to study both natural history and pathogenic mechanism of BPVs [56-58]. In 2013, we described the presence of cytogenetic aberrations in primary cell cultures derived from BPV-infected cutaneous, urinary bladder and esophageal papilloma [40] similar to those verified in lymphocyte shortterm culture of BPV-infected animals [2,39]. Cytogenetic damages was also detected in primary cell cultures derived from BPV-infected bovine, equine and canine papillomas [60]. Using cell lines derived from primary cultures of BPV-infected cutaneous papilloma, fibropapilloma and esophageal carcinoma, the same cell lines employed in this study, we showed that virus infection promotes metabolic deregulation, leading to oxidative stress as a consequence of pro-oxidant action of BPV-1 E6 oncoprotein [57]. Currently, we also verified that cell lines derived from BPV-infected neoplasms acquire a stem-cell-like and migratory biomarker phenotype acquisition [58]. Despite these data show the potential of BPV-infected cell lines and/or primary cultures as model to study the viral biology and pathology, especially on oncogenesis, up to date the in vitro systems remains considered as not able to develop a productive infection. This is a reflection of viral replication paradigm, which states that the BPV replication is dependent of epithelial cell differentiation, since the expression of capsid proteins (L1 and L2) is restrict to the most differentiated epithelium layers $[8,61]$.

However, in last years it was verified that presence of BPV DNA sequences in different sites not passive of cell differentiation, including urine, spermatozoa [62], blood [2,11,39,63-65] and placenta [53]. Considering that the $\mathrm{L} 1$ protein expression is verified in sites of viral assembly, once this protein is able to self-organize in pentameric structures that composes the BPV capsid [66], L1 immunodetection is pointed out as the main evidence of productive infection [51,67]. Based on BPV DNA sequences identification and L1 immunodetection, Roperto et al. [52] and Melo et al. [51] described the productive infection in lymphocytes and, later in placenta [53].

Considering that cell lines derived from BPV-infected neoplasm are able to mimetic the in vivo viral pathology, verified by the cytogenetic aberrations [40], DNA damages, metabolic deregulation 


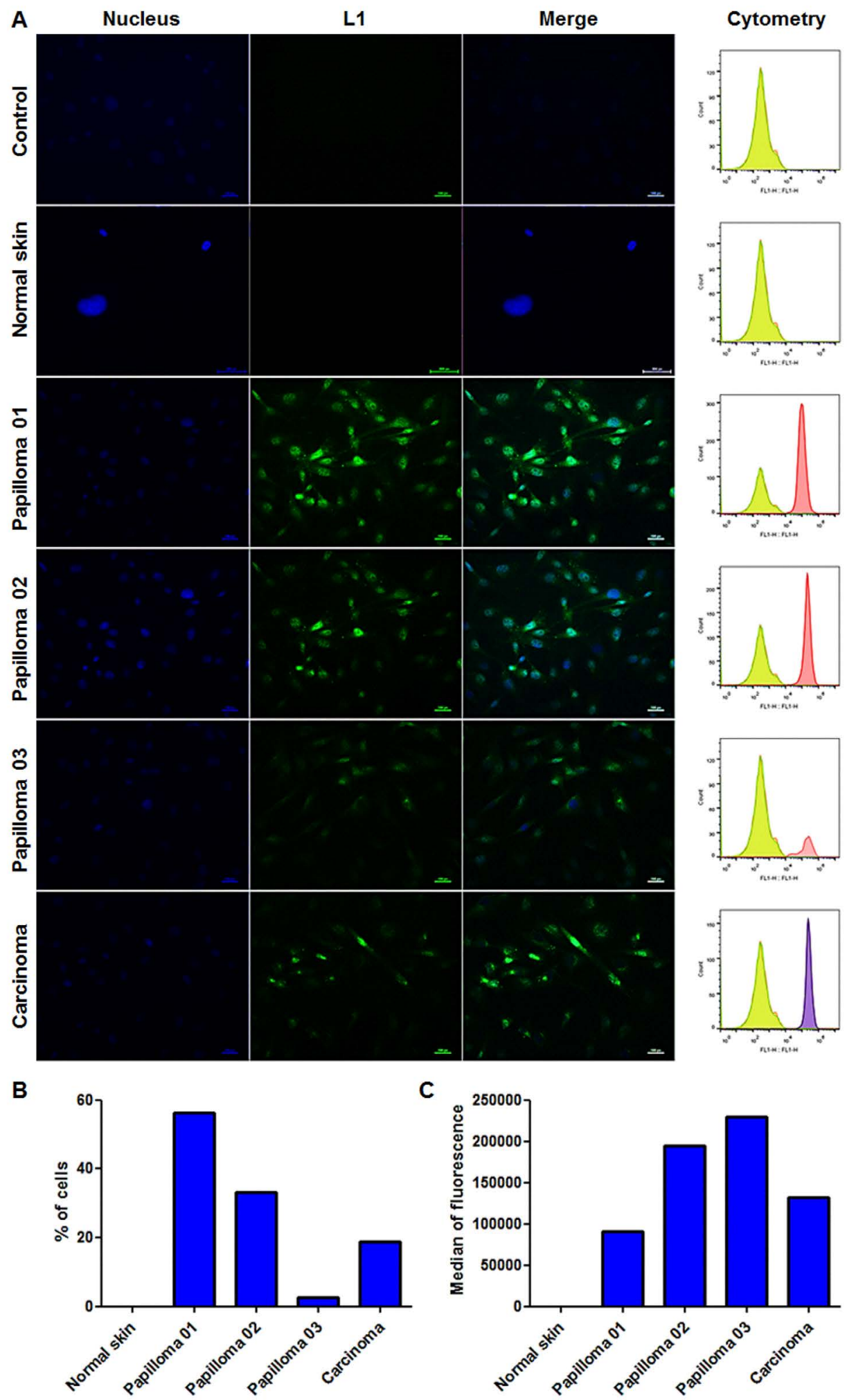

Figure 2. Immunodetection of L1 capsid protein by immunofluorescence and flow cytometry. A) Immunofluorescence analysis showing: absence of unspecific labeling in cells derived from cutaneous papilloma only incubated with the secondary antibody conjugated with FITC (control); absence of labeling and, therefore, L1 expression in BPV-free normal skin cells; cytoplasmic and nuclear immunodetection of L1 protein in cells derived from cutaneous papilloma (papilloma 01), fibropapilloma (papilloma 02 and 03) and esophageal carcinoma. Flow cytometry analysis showing absence of unspecific labeling in cells derived from cutaneous papilloma only incubated with the secondary antibody conjugated with Alexa Fluor 488 (control), absence of L1 expression in normal skin cells; immunodetection of L1 protein in cells derived from cutaneous papilloma (papilloma 01), fibropapilloma (papilloma 02 and 03) and esophageal carcinoma. B) Cell percentage expressing L1 protein. C) Median of fluorescent intensity (MFI) of L1 expressing cells. Total of 10,000 events analyzed. Cells in third passage (P3). 

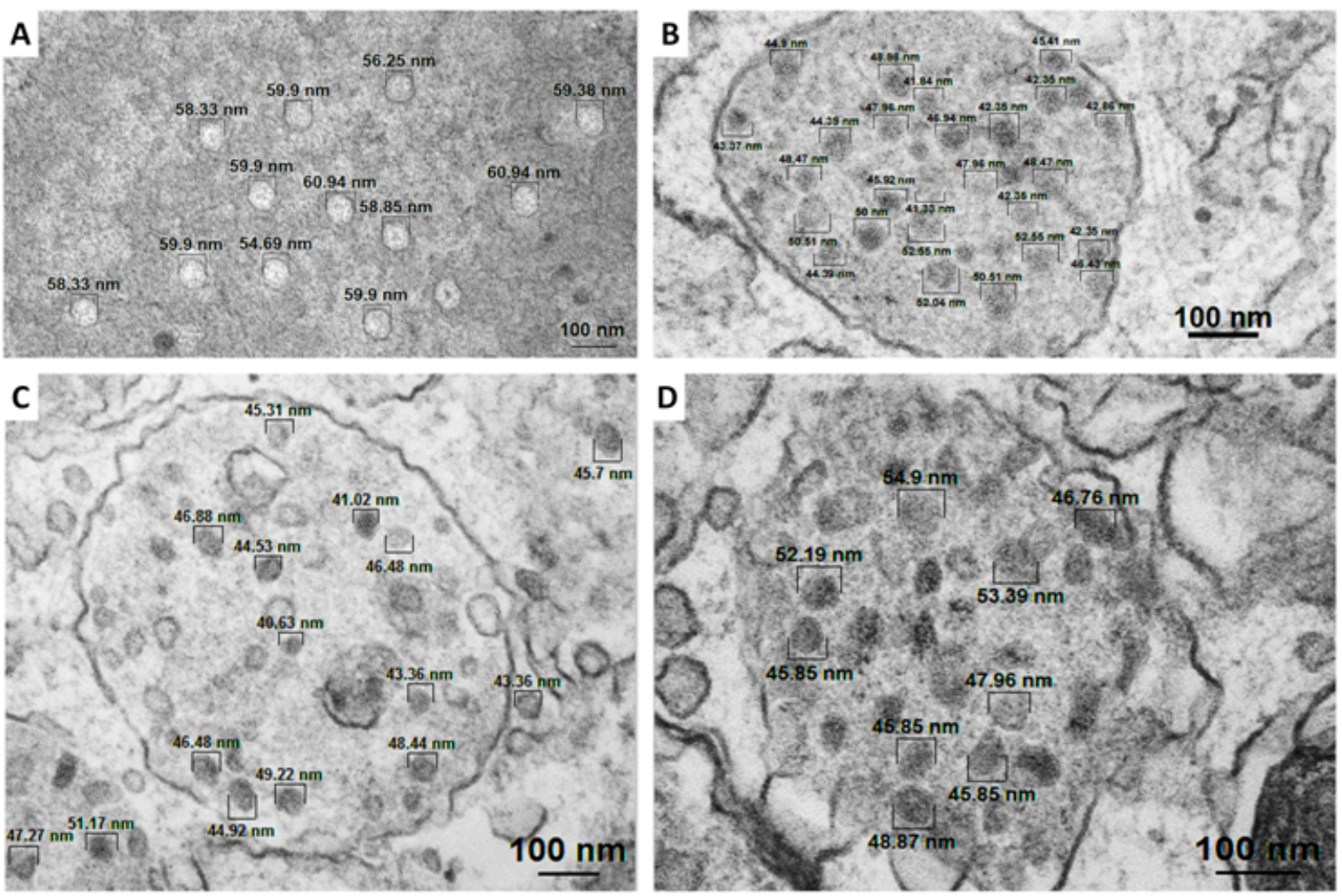

Figure 3. Electron micrographs showing spherical and electron-dense particles observed in: A) cytoplasm of cutaneous papilloma cells (papilloma 01), cytoplasmic vesicles of fibropapillomas (B - papilloma 02 and $\mathrm{C}$ - papilloma 03) and D) esophageal carcinoma. Analysis performed in the sixth passage (P6).
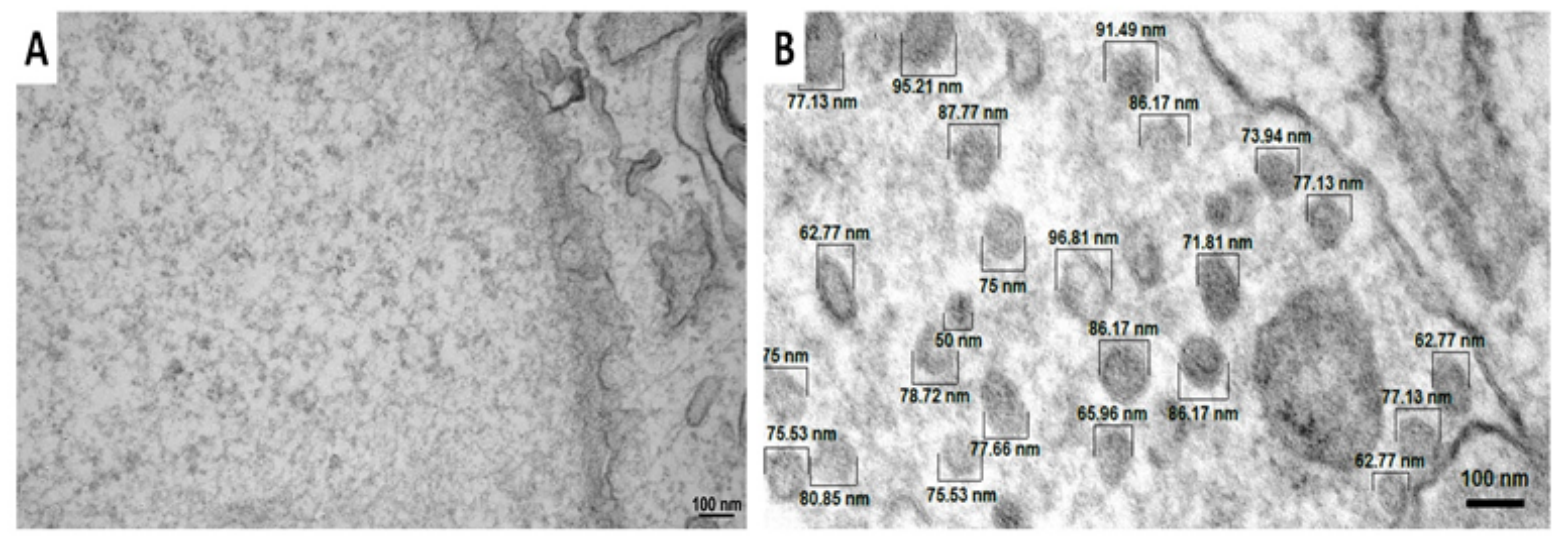

Figure 4. Electron micrographs of BPV-free normal skin cells showing the absence of virion-like particles into the nucleus and the presence of membranous vesicles with diameter up to $75.00 \mathrm{~nm}$ not compatible with BPV virion morphology. Analysis performed in the sixth passage (P6).

[57] and migratory phenotype acquisition [58] in this study we investigated the L1 expression and the presence of BPV particles in cell lines derived from BPV-infected cutaneous papilloma, fibropapilloma and esophageal carcinoma, in which we previous described the maintenance of DNA sequences of BPV-1,2 and 4 [57]. We detected the nuclear and cytoplasmic labelling of L1 protein in cutaneous papilloma, fibropapilloma and esophageal carcinoma cells, but not in BPV-free normal skin cells (Figure 2). These results were confirmed by flow cytometry (Figure 2), suggesting the in vitro viral assembly. This because, considering the nature obtaining maximum effect for lower energy cost, it will not expect the L1 expression in primary cell cultures if there was not viral assembly.
Once the viruses are smaller than their host, the electron microscopy (EM) is recognized as the best method to identify BPV particles [59], since this technique allows to analyze the ultrastructure with high resolution [68]. However, with the advent of molecular biology, the PCR became the most used method to viral identification. But, the PCR does not allow to identify viral particles, making the EM a mandatory method to demonstrate the productive infection. Based on these data, the different cell lines, in the sixth passage (P6), were subjected to EM analysis. Under EM, BPV virions are visualized as non-enveloped isometric particles, with electron-dense spherical morphology and a diameter of 45-60 $\mathrm{nm}[51,59,69]$. 


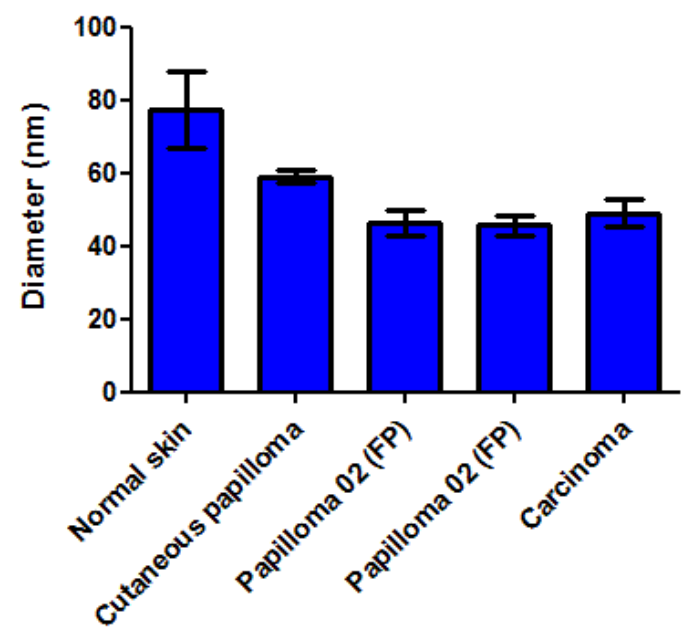

Figure 5. Morphometric analysis of particles detected by electron microscopy of different cell lines. Results show the presence of particles with a diameter of 41.02-61.94 nm in all cell lines derived from BPV-infected neoplasm. Cells from normal skin show the presence of particles with diameter up to $75.00 \mathrm{~nm}$, not compatible with the BPV virion morphology.

EM results showed the presence of electron-dense spherical structures, with isometric morphology and a diameter among 41.02 to $60.94 \mathrm{~nm}$, compatible with BPV particles (Figure 3). These structures were observed in cytoplasmic vesicles of primary cell cultures derived from cutaneous papilloma, fibropapillom and esophageal carcinoma (Figure 3). BPV-free normal skin cells showed the presence of spherical structures, disperse in cytoplasm, with envelope and diameter higher to $75.0 \mathrm{~nm}$ (Figures 4 and 5), being non-compatible with BPV particles. These results are strong evidences of productive infection in primary cells cultures.

BPV viral assembly in cultures cells are plausible, once different of HPV, BPV does not integrate with host genome, being verified in episomal form. Thus, the virus remains its complete genome, being able to codify all proteins, including L proteins, responsible for the viral assembly. In conclusion, our data suggest for the first time the BPV productive infection in vitro. These results indicate that primary cell cultures derived from BPV-infected lesion can be useful models to study the oncogenic mechanism of these viruses.

\section{Acknoledgements}

The authors thanks Fundação de Amparo à Pesquisa do Estado de São Paulo (FAPESP, process 2014/20617-5) and Fundação Buntantan by the financial support.

\section{References}

1. He Z, Meng Q, Qiao J, Peng Y, Xie K, et al. (2016) Mixed Nipple Infections Caused by Variant of BPV3 and a Putative New Subtype of BPV in Cattle. TransboundEmerg Dis 63: e140-143.[Crossref]

2. Stocco dos Santos RC, Lindsey CJ, Ferraz OP, Pinto JR, Mirandola RS, et al. (1998) Bovine papillomavirus transmission and chromosomal aberrations: an experimental model. J Gen Virol79: 2127-2135.[Crossref]

3. Campo MS (2002) Animal models of papillomavirus pathogenesis. Virus Res 89: 249261.[Crossref]

4. Carvalho RF, Araldi RP, Lima TAN, Módolo DG, Mazzuchelli-de-Souza J, et al. (2016) Synergic association between the bovine papillomavirus infection and alimentary cofactors. Reference Module in Food Bioscience pp: 1-10.

5. 5. Yaguiu A, Carvalho C, Freitas A, Gustavo L, Góes B, Dagli L, et al. (2006) Papillomatosis in cattle: in situ detection of bovine papillomavirus DNA sequences in reproductive tissues. Brazilian J Morphol Sci 23:525-9.
6. Monteiro V, Coelho M, Carneiro A, Silva R, Teixeira M, et al. (2008) Descriçãoclínica e histopatológica da papilomatosecutânea bovina (BPV). CiênciaAnim Bras10: 550 560

7. Turk N, Župancic Ž, Starešina V, Kovac S, Babic T, et al. (2005) Severe bovine papillomatosis?: detection of bovine papillomavirus in tumour tissue and efficacy of treatment using autogenous vaccine and parammunity inducer. Vet Arh75:391-397.

8. Araldi RP Assaf SM, Carvalho RF, Carvalho MA (2017) Papillomaviruses: a systematic review. Genet MolBiol[Crossref]

9. Cascales R, Alcantara B, Molinari B, Bodnar L, Filippsen P, et al. (2009) Estudohistopatológico de lesõesneoplásicasbenignas, determinadaspelopapilomavírusbovino, localizadoemtetos e úberes de vacasleiteiras. An do XVIII EncontroAnu,IniciaçãoCientífica.

10. Gil da Costa RM, Medeiros R (2014) Bovine papillomavirus: opening new trends for comparative pathology. Arch Virol159: 191-198.[Crossref]

11. Araldi R, Melo T, Diniz N, Carvalho R, Beçak W, et al. (2013) Bovine papillomavirus clastogenic effect analyzed in comet assay. Biomed Res Intpp:1-7.

12. Silva MA, De Albuquerque BM, Pontes NE, Coutinho LC, Leitão MC, et al (2013) Detection and expression of bovine papillomavirus in blood of healthy and papillomatosis-affected cattle. Genet Mol Res 12: 3150-3156.[Crossref]

13. Grindatto A, Ferraro G, Varello K, Crescio MI, Miceli I, et al. (2015) Molecular and histological characterization of bovine papillomavirus in North West Italy. Vet Microbiol180: 113-117.[Crossref]

14. Hamad MA, Al-Shammari AM, Odisho SM, Yaseen NY (2016) Molecular and Phylogenetic Analysis of Bovine Papillomavirus Type 1: First Report in Iraqi Cattle. AdvVirol2016: 2143024.[Crossref]

15. Silva F, Cibulski S, Daudt C, Weber M, Guimarães L, et al. (2016) Novel bovine papillomavirus type discovered by rolling-circle amplification coupled with nextgeneration sequencing. PLoS Onepp: 1-11.

16. Bocaneti F, Altamura G, Corteggio A, Velescu E, Borzacchiello G (2015) Expression of bcl-2 and p53 in bovine cutaneous fibropapillomas. Infect Agent Cancer 10: 2.[Crossref]

17. Shafti-Keramat S, Schellenbacher C, Handisurya A, Christensen N, Reininger B, et al (2009) Bovine papillomavirus type 1 (BPV1) and BPV2 are closely related serotypes. Virology393: 1-6.[Crossref]

18. Jarrett W, Campo M, O’Neil B, Laird H, Coggins L (1984) A novel bovine papillomavirus (BPV-6) causing true epithelial papillomas of the mammary gland skin: a member of a proposed new BPV subgroup. Virology 136:255-264.

19. Munday J, Thomson N, Dunowska M, Knight C, Laurie R, et al. (2015) Genomic characterisation of the feline sarcoid-associated papillomavirus and proposed classification as Bos taurus papillomavirus type 14. Vet Microbiol177: 289-295.

20. Pangty K, Singh S, Goswami R, Saikumar G, Somvanshi R (2010) Detection of BPV-1 and -2 and quantification of BPV-1 by real-time PCR in cutaneous warts in cattle and buffaloes. TransboundEmerg Dis57: 185-196.[Crossref]

21. Maiolino P, Ozkul A, Sepici-Dincel A, Roperto F, Yücel G, et al. (2013) Bovine papillomavirus type 2 infection and microscopic patterns of urothelial tumors of the urinary bladder in water buffaloes. Biomed Res Int p:937918.

22. Roperto S, Russo V, Ozkul A, Sepici-Dincel A, Maiolino P, et al. (2013) Bovine papillomavirus type 2 infects the urinary bladder of water buffalo (Bubalusbubalis) and plays a crucial role in bubaline urothelial carcinogenesis. J Gen Virol94:403-408.

23. Van Dyk E, Bosman AM, van Wilpe E, Williams JH, Bengis RG, et al. (2011) Detection and characterisation of papillomavirus in skin lesions of giraffe and sable antelope in South Africa. J S Afr Vet Assoc82: 80-85.[Crossref]

24. Williams J, van Dyk E, Nel P, Lane E, van Wilpe E, et al. (2011) Pathology and immunohistochemistry of papillomavirus-associated cutaneous lesions in Cape mountain zebra, giraffe, sable antelope and African buffalo in South Africa. $J$ South Africa Vet Assoc82:97-106.

25. Kidney B, Berrocal A (2008) Sarcoids in two captive tapirs (Tapirusbairdii): clinical, pathological and molecular study (2008) Vet Dermatol19:380-384.

26. Löhrdr C, Juan-sallésd C, Rosas-Rosas A, García A, Garnerd M, et al. (2005) Sarcoids in captive zebras (Equus burchellii): association with bovine papillomavirus type 1 infection. $J$ Zoo Wildl Med36:c74-81.

27. Bam J, Kumar P, Leishangthem G, Saikia A, Somvanshi R (2013) Spontaneous cutaneous papillomatosis in yaks and detection and quantification of bovine papillomavirus-1 and -2. TransboundEmerg Dis60:475-480. 
28. Dong J, Zhu W, Haga T (2016) Papillomavirus in yaks: the isolates of bovine papillomavirus type 1 have a high possibility of belonging to a novel type. $J$ Vet Med Sci 78: 1059-1061.[Crossref]

29. Bergvall KE (2013) Sarcoids. Vet Clin North Am Equine Pract29: 657-671.[Crossref]

30. Yuan Z, Gallagher A, Gault EA, Campo MS, Nasir L (2007) Bovine papillomavirus infection in equine sarcoids and in bovine bladder cancers. Vet $J$ 174: 599-604.[Crossref]

31. Yuan Z, Gallagher A, Gault E, Campo M, Nasir L (2007) Bovine papillomavirus infection in equine sarcoids and in bovine bladder cancers. Vet $J$ 174:599-604.

32. Nasir L, Reid SW (1999) Bovine papillomaviral gene expression in equine sarcoid tumours. Virus Res 61: 171-175.

33. Knottenbelt DC (2005) A suggested clinical classification for the equine sarcoid. Clin Tech Equine Pract 4:278-95.[Crossref]

34. Munday JS (2014) Bovine and human papillomaviruses: a comparative review. Vet Pathol 51: 1063-1075.[Crossref]

35. Borzacchiello G, Ambrosio V, Roperto S, Poggiali F, Tsirimonakis E, et al. (2003) Bovine papillomavirus type 4 in oesophageal papillomas of cattle from the south of Italy. J Comp Pathol 128: 203-206.[Crossref]

36. Araldi R, Módolo D, De-Sá-Júnior P, Consonni S, Carvalho R, et al. (2016) Genetics and metabolic deregulation following cancer initiation: A world to explore. Biomed Pharmacother 82:449-458.

37. Potocki L, Lewinska A, Klukowska-Rötzler J, Bielak-zmijewska A, Grabowska W, et al. (2014) Sarcoid-derived fibroblasts: links between genomic instability, energy metabolism and senescence. Biochimie 92:163-172.

38. Araldi RP, Melo TC, Neves AC, Spadacci-Morena DD, Magnelli RF, et al. (2015) Hyperproliferative action of bovine papillomavirus: genetic and histopathological aspects. Genet Mol Res 14: 12942-12954.[Crossref]

39. Melo TC, Diniz N, Campos SR, Ferraz OP, Lindsey CJ, et al. (2011) Cytogenetic studies in peripheral blood of bovines afflicted by papillomatosis. Vet Comp Oncol 9: 269-274.[Crossref]

40. Campos S, Melo T, Assaf S, Araldi R, Mazzuchelli-de-Souza J, et al. (2013) Chromosome aberrations in cells infected with bovine papillomavirus: comparing cutaneous papilloma, esophagus papilloma, and urinary bladder lesion cells. ISRN Oncol 2013:910849.

41. DeMasi J, Huh K, Nakatani Y, Münger K, Howley P (2005) Bovine papillomavirus E7 transformation function correlates with cellular p600 protein binding. Proc Natl Acad Sci USA 102:11486-11491.

42. Bohl J, Hull B, Vande Pol SB (2001) Cooperative transformation and coexpression of bovine papillomavirus type $1 \mathrm{E} 5$ and E7 proteins. $J$ Virol 75: 513-521.[Crossref]

43. DiMaio D, Mattoon D (2001) Mechanisms of cell transformation by papillomavirus E5 proteins. Oncogene 20: 7866-7873.[Crossref]

44. Doorbar J (2016) Model systems of human papillomavirus-associated disease. J Patho 238: 166-179. [Crossref]

45. McBride A, Dlugosz A, Baker C (2000) Production of infectious bovine papillomavirus from cloned viral DNA by using an organotypic raft/xenograft technique. Proc Nat Acad Sci USA 97:1-6.

46. White EA, Howley PM (2013) Proteomic approaches to the study of papillomavirushost interactions. Virology 435: 57-69.[Crossref]

47. Cerqueira C, Pang Y, Day P, Thompson C, Buck C, et al. (2016) A cell-free assembly system for generating infectious Human Papillomavirus Type 16 capsids implicates a size discrimination mechanism for preferential viral genome packaging. J Virol 90: 1096-1107.

48. Brobst D, Hinsman EJ (1966) Electron microscopy of the bovine cutaneous papilloma. Pathol Vet 3: 196-207. [Crossref]

49. Buck CB, Pastrana DV, Lowy DR, Schiller JT (2004) Efficient intracellular assembly of papillomaviral vectors. J Virol 78: 751-757.[Crossref]

50. Buck C, Day P, Trus B (2013) The papillomavirus major capsid protein L1. Virology 445:169-174.

51. Melo T, Araldi R, Pessoa N, De-Sá-Júnior P, Carvalho R, et al. (2015) Bos taurus papillomavirus activity in peripheral blood mononuclear cells: demonstrating a productive infection. Genet Mol Res 14:16712-16727.

52. Roperto S, Comazzi S, Ciusani E, Paolini F, Borzacchiello G, et al. (2011) PBMCs are additional sites of productive infection of bovine papillomavirus type 2.J Gen Virol92: 1787-1794.[Crossref]
53. Roperto S, Borzacchiello G, Esposito I, Riccardi M, Urraro C, et al. (2012) Productive infection of bovine papillomavirus type 2 in the placenta of pregnant cows affected with urinary bladder tumors. PLoS One 7:1-9.

54. Foresta C, Bertoldo A, Garolla A, Pizzol D, Mason S, et al. (2013) Human papillomavirus proteins are found in peripheral blood and semen $\mathrm{Cd} 20+$ and $\mathrm{Cd} 56+$ cells during HPV-16 semen infection. BMC Infectious Dis 13:593.

55. Chiou H, Wu M, Liaw Y, Cheng Y, Wong R, et al. (2003) The presence of human papillomavirus type 16/18 DNA in blood circulation may act as a risk marker of lung cancer in Taiwan. Cancer 97:1558-1563.

56. Campos S, Trindade C, Ferraz O, Giovanni D, Lima A, et al. (2008) Can established cultured papilloma cells harbor bovine papillomavirus? Genet Rolecular Res 7:11191126.

57. Araldi R, De-Sá-Júnior P, Magnelli R, Modolo D, Mazzuchelli-de-Souza J, et al (2016) Primary cultures derived from bovine papillomavirus-infected lesions as mode to study metabolic deregulation. J Cancer Res Ther Oncol 4:1-18.

58. Araldi R, Lima T, Módolo D, Mazzuchelli-de-Souza J, Magnelli R, et al. (2017) Analysis of stem-cell and migratory phenotype in primary cultures derived from BPVinfected benign and malignant neoplasms. J Cancer Res Ther Oncol 5:1-13.

59. Araldi RP, Giovanni DN, Melo TC, Diniz N, Mazzuchelli-de-Souza J, et al. (2014) Bovine papillomavirus isolation by ultracentrifugation. $J$ Virol Methods 208: 119-124. [Crossref]

60. Simões R, Barth O (2016) Chromosome aberrations as a biomarker for genomic instability in cell cultures originated from bovines, canines and equines infected with papillomavirus. Int J Appl Sci Biotechnol 4:104-112.

61. Munday JS (2014) Papillomaviruses in felids. Vet J 199: 340-347. [Crossref]

62. Lindsey C, Almeida M, Vicari C, Carvalho C, Yaguiu A, et al. (2009) Bovine papillomavirus DNA in milk, blood, urine, semen, and spermatozoa of bovine papillomavirus-infected animals. Genet Mol Res 8:310-318.

63. Brandt S, Haralambus R, Schoster A, Kirnbauer R, Stanek C (2008) Peripheral blood mononuclear cells represent a reservoir of bovine papillomavirus DNA in sarcoidaffected equines. J Gen Virol 89:1390-5.

64. Roperto S, Brun R, Paolini F, Urraro C, Russo V, et al. (2008) Detection of bovine papillomavirus type 2 in the peripheral blood of cattle with urinary bladder tumours: possible biological role. J Gen Virol89:3027-3033.

65. Araldi RP, Carvalho RF, Melo TC, Diniz NS, Sant'Ana TA, et al. (2014) Bovine papillomavirus in beef cattle: first description of BPV-12 and putative type BAPV8 in Brazil. Genet Mol Res 13: 5644-5653. [Crossref]

66. Módolo DG, Araldi RP, Mazzuchelli-de-Souza J, Pereira A, Pimenta DC, et al. (2017) Integrated analysis of recombinant BPV-1 L1 protein for the production of a bovine papillomavirus VLP vaccine. Vaccine 35: 1590-1593. [Crossref]

67. Nasir L, Reid SW (1999) Bovine papillomaviral gene expression in equine sarcoid tumours. Virus Res 61: 171-175. [Crossref]

68. Shu X, Lev-Ram V, Deerinck T, Qi Y, Ramko E, et al. (2011) A genetically encoded tag for correlated light and electron microscopy of intact cells, tissues, and organisms. PLoS Biol 9:e1001041.

69. Tanaka H, Joazeiro P (1998) Microscopiaeletrônica de transmissão no diagnóstico de papilomavírus. In: Bibbo M, Moraes-Filho A (Eds)LesõesRelac. à infecçãopor HPV no tratao anogenital. 1a, Rio de Janeiro: Revinter p. 166

70. Furukawa T, Duguid W, Rosenberg L, Viallet J, Galloway D, et al. (1996) Long-term culture and immortalization of epithelial cells from normal adult human pancreatic ducts transfected by the E6E7 gene of human papilloma virus.Am J Pathol148: 17631770 .

71. Fichorova R, Rheinwald J, Anderson D (1997) Generation of papillomavirusimmortalized cell lines from normal human ectocervical, endocervical, and vagina epithelium that maintain expression of tissue-specific differentiation proteins. Biol Reprod 57: 847-855.

72. Klingelhutz AJ, Foster SA, McDougall JK (1996) Telomerase activation by the E6 gene product of human papillomavirus type 16. Nature 380: 79-82.[Crossref]

73. Stöppler H, Hartmann D, Sherman L, Schlegel R (1997) The human papillomavirus type 16 E6 and E7 oncoproteins dissociate cellular telomerase activity from the maintenance of telomere length. J Biol Chem 272: 13332-13337.

74. Elbel M, Carl S, Spaderna S, Iftner T (1997) A comparative analysis of the interactions of the E6 proteins from cutaneous and genital papillomaviruses with p53 and E6AP in correlation to their transforming potential. Virology 239: 132-149. 
75. Alfandari J, Shnitman-Magal S, Jackman A, Schlegel R, Gonen P, et al. (1999) HPV16 E6 oncoprotein inhibits apoptosis induced during serum-calcium differentiation of foreskin human keratinocytes. Virology 257: 383-396.

76. Flores E, Allen-hoffmann B, Lee D, Sattler C, Lambert P (1999) Establishment of the human papillomavirus type 16 (HPV-16) life cycle in an immortalized human foreskin keratinocyte cell line. Virology 354: 344-354.

77. Bohl J, Das K, Dasgupta B, Vande Pol S (2000) Competitive binding to a charged leucine motif represses transformation by a papillomavirus E6 oncoprotein. Virology 271: $163-170$

78. Das K, Bohl J, Vande Pol SB (2000) Identification of a second transforming function in bovine papillomavirus type $1 \mathrm{E} 6$ and the role of E6 interactions with paxillin, E6BP, and E6AP. J Virol 74: 812-816.[Crossref]

79. Kao WH, Beaudenon SL, Talis AL, Huibregtse JM, Howley PM (2000) Human papillomavirus type 16 E6 induces self-ubiquitination of the E6AP ubiquitin-protein ligase. J Virol 74: 6408-6417.[Crossref]

80. Jackson S, Storey A (2000) E6 proteins from diverse cutaneous HPV types inhibit apoptosis in response to UV damage. Oncogene 19: 592-598.[Crossref]

81. Duensing S, Lee L, Duensing A, Basile J, Piboonniyom S, et al. (2000) The human papillomavirus type $16 \mathrm{E} 6$ and E7 oncoproteins cooperate to induce mitotic defects and genomic instability by uncoupling centrosome uplication from the cell division cycle. Proc Natl Acad Sci USA 97: 10002-10007.

82. Duensing S, Münger K (2002) The human papillomavirus type 16 E6 and E7 oncoproteins independently induce numerical and structural chromosome instability. Cancer Res 62: 7075-7082

83. Grigolo B, Roseti L, Neri S, Gobbi P, Jensen P, et al. (2002) Human articular chondrocytes immortalized by HPV-16 E6 and E7 genes: Maintenance of differentiated phenotype under defined culture conditions. Osteoarthr Cartil10: 879-889.

84. Gewin L, Myers H, Kiyono T, Galloway D (2004) Identification of a novel telomerase repressor that interacts with the human papillomavirus type-16 E6/E6-AP complex. Genes Dev18: 2269-2282.

85. Azzimonti B, Dell'Oste V, Borgogna C, Mondini M, Gugliesi F, et al. (2009) The epithelial-mesenchymal transition induced by keratinocyte growth conditions is overcome by E6 and E7 from HPV16, but not HPV8 and HPV38: Characterization of global transcription profiles. Virology 388: 260-269.

86. Krawczyk E, Suprynowicz F, Sudarshan S, Schlegel R (2010) Membrane orientation of the human papillomavirus type 16 E5 oncoprotein. J Virol 84: 1696.

87. Hyland P, Mcdade S, Mccloskey R, Dickson G, et al. (2011) Evidence for alteration of EZH2, BMI1, and KDM6A and epigenetic reprogramming in Human papillomavirus type 16 E6/E7-expressing keratinocytes. J Virol 85: 10999.

88. Khan J, Davy C, McIntosh P, Jackson D, Hinz S, et al. (2011) Role of calpain in the formation of human papillomavirus type $16 \mathrm{E} 1^{\wedge} \mathrm{E} 4$ amyloid fibers and reorganization of the keratin network. J Virol 85: 9984-9997.

89. Morrison M, Morreale R, Akunuru S, Kofron M, Zheng Y, et al. (2011) Targeting the human papillomavirus E6 and E7 oncogenes through expression of the bovine papillomavirus type $1 \mathrm{E} 2$ protein stimulates cellular motility. J Virol 85: 10487-10498.
90. Hufbauer M, Biddle A, Borgogna C, Gariglio M, Doorbar J, et al. (2013) Expression of betapapillomavirus oncogenes increases the number of keratinocytes with stem celllike properties. $J$ Virol 87: 12158-12165.[Crossref]

91. Boon S, Tomaic V, Thomas M, Roberts S, Banks L (2015) Cancer-causing human papillomavirus E6 proteins display major differences in the phospho-regulation of their PDZ interactions. J Virol 89: 1579-1586.

92. Gauson EJ, Wang X, Dornan ES, Herzyk P, Bristol M, et al. (2016) Failure to interact with Brd4 alters the ability of HPV16 E2 to regulate host genome expression and cellular movement. Virus Res 211: 1-8.[Crossref]

93. Meischke HR (1979) In vitro transformation by bovine papilloma virus. J Gen Virol43: 473-487.[Crossref]

94. Lindgren V, Sippola-Thiele M, Skowronski J, Wetzel E, Howley P, Hanahan D (1989) Specific chromosomal abnormalities characterize fibrosarcomas of bovine papillomavirus type 1 transgenic mice. Proc Natl Acad Sci USA86: 5025-5029.

95. Hamad M, Al-Banna A, Yaseen N (2011) Cell culture established from warts of bovine papilloma $J$ Vet Sci 4: 77-81.

96. Steinberg B, Abramson A, Meade R (1982) Culture of human laryngeal papilloma cells in vitro. Otolaryngol - Head Neck Surg 90: 728-735.

97. Pater M, Pater A (1985) Human papillomavirus types 16 and 18 sequences in carcinoma cell lines of the cervix. Virology 145: 313-318.

98. McCance DJ, Kopan R, Fuchs E, Laimins LA (1988) Human papillomavirus type 16 alters human epithelial cell differentiation in vitro. Proc Natl Acad Sci U S A 85: 7169 7173.[Crossref]

99. Reppucci AD, DiLorenzo TP, Abramson AL, Steinberg BM (1991) In vitro modulation of human laryngeal papilloma cell differentiation by retinoic acid. Otolaryngol Head Neck Surg 105: 528-532.[Crossref]

100. Shen M, Wu S, Chou C (1996) Volume-sensitive chloride channels in the primary culture cell of human cervical carcinoma. BiochemBiophys Acta 1315: 138-144.

101. López-Ocejo O, Viloria-Petit A, Bequet-Romero M, Mukhopadhyay D, Rak J, et al (2000) Oncogenes and tumor angiogenesis: the HPV-16 E6 oncoprotein activates the vascular endothelial growth factor (VEGF) gene promoter in a p53 independent manner. Oncogene 19: 4611-20.

102. Kadaja M, Sumerina A, Ojarand M, Ustav E, Ustav M (2007) Genomic instability of the host cell induced by the human papillomavirus replication machinery. EMBO J26: $2180-2191$

103. Kadaja M, Isok-Paas H, Laos T, Ustav E, Ustav M (2009) Mechanism of genomic instability in cells infected with the high-risk human papillomaviruses. PLoS Pathog 5: e1000397.[Crossref]

104. Hu Z, Müller S, Qian Q, Xu J, Kim S, et al. (2015) Human papillomavirus 16 oncoprotein regulates the translocation of $\beta$-catenin via the activation of epidermal growth factor receptor. Cancer 121: 214-225.

Copyright: (C2017 Araldi RP. This is an open-access article distributed under the terms of the Creative Commons Attribution License, which permits unrestricted use, distribution, and reproduction in any medium, provided the original author and source are credited. 